\title{
ANALYSES OF REGULATIONS REGARDING ACCOMMODATION FACILITIES CATEGORISATION IN RURAL TOURISM IN SERBIA
}

\author{
Svetlana Vukosavi ${ }^{1}$, Vuk Garača ${ }^{2}$, Milan Bradić ${ }^{3}$ \\ *Corresponding author E-mail: svetlana.vukosav@dgt.uns.ac.rs
}

A R T I C L E I N F O
Review Article
Received: 12 March2018
Accepted: 05 June 2018
doi:10.5937/ekoPolj1802769V
UDC 338.48-44(1-22):340.134(497.11)

Keywords:

law regulation, categorisation, accommodation facilities, rural tourism, Serbia

JEL: Q5, O13, O14, Z320

\section{A B S T R A C T}

The paper analyze the regulation on categorization of accommodation that relate to accommodation in rural tourism. The main aim of the paper is to estimate the point to which legal and administrative procedures reached in recognizing new forms of accommodation in rural tourism in Serbia as well as the level of compliance of legislation with some of the countries in the region. The results of the research render highly significant data on identification of roles, goals, procedures and purpose of the categorization aimed at pursuing market trends which is of crucial importance for tourism stakeholders. Moreover, the adjustments to international standards have become the imperative for Serbia to successfully continue the EU accession in this tourism branch as well.

(C) 2018 EA. All rights reserved.

\section{Introduction}

Mass tourism travels and intensive hospitality development lead to intense competition in the process of obtaining more favourable positions within the network of accommodation capacities. Competition and market may stand as sufficient regulators of the necessary minimum for service quality and prices, primarily in developed countries with longer tourism tradition. Participation of more countries with different level of social and economic development into receptive tourism on the one hand, and participation of various population groups in domestic and international tourism travel on the other hand impose the need for categorisation (Bradić, 2008). In economically underdeveloped countries with small scale tourism, as well as regions with no competition, there is the objective need for protection of tourists staying in a categorised accommodation unit that will guarantee appropriate quality and price (Vukosav, 2010).

1 PhD Svetlana Vukosav, associate professor, Faculty of Sciences, Department of geography, tourism and hotel management,Trg Dositeja Obradovića 3, Novi Sad, Serbia, Phone: 00381214852848, svetlana.vukosav@dgt.uns.ac.rs

2 PhD Vuk Garača, associate professor, Faculty of Sciences, Department of geography, tourism and hotel management,Trg Dositeja Obradovića 3, Novi Sad, Serbia, Phone: 00381214852837,vuk.garaca@dgt.uns.ac.rs

$3 \mathrm{PhD}$ Milan Bradić, associate professor, Faculty of Sciences, Department of geography, tourism and hotel management,Trg Dositeja Obradovića 3, Novi Sad, Serbia, Phone:00381214852848, milan.bradic@dgt.uns.ac.rs 
Therefore, there is the need for law regulation in this area and precise definition of accommodation standards. World trends indicate that rural tourism is an ever growing concept with increasing refined needs of domestic and international demand. Rural tourism is a combination of various aspects of experience, sharing, and presenting rural form of living. Such rural experience may be defined with regard to rural activities and accommodation. Combination of those forms is the essence of rural tourism. What makes rural tourism unique is the contact with nature and personal contact with the local population. Rural accommodation combines different forms of tourism that portrait rural life, art, culture and heritage in rural areas (UWTO, 2010).

Serbia possesses excellent conditions for rural tourism development owing to its geographical position, versatile landscape for all forms of recreation, gastronomy, folklore, and rich cultural heritage (Guidebook for rural hosts, 2014). However, an enormous problem of accommodation capacities in rural areas and the major obstacle for rural tourism development is the categorisation of establishments. Regulation in this branch is partially disordered (Penić, 2015). It is complicated to compare standardisation of an ethno house to that of a local farm in Vojvodina. Moreover, the owners of both slow down the implementation of fiscalisation process. Nevertheless, more attention should be paid to standardisation of services and environment protection. Joint activities would undeniably lead to more opportunities in individual and collective promotion of rural tourism.

Gajić et al., (2017) concluded that the tourism facilities in rural tourism in Serbia cover relatively small areas, fail to host a large number of tourists, and have limited expansion opportunities. This research also indicates that categorisation is inadequate and overneeded and in that sense the aim of the paper is to estimate the point to which legal and administrative procedures reached in recognising new forms of accommodation in rural tourism in Serbia.

\section{Role and importance of classification and categorisation in (rural) tourism}

Growing number of participants in international tourism imposes the need for standardisation in the sense of separating different types and categories of hospitality units on the basis of different criteria, i.e. standards. The standards precisely define the requirements that need to be fulfilled in order to start hospitality business, describe various similar characteristics as the basis for object classification, determine the factors of the object type and verify elements that enable ranking of similar establishments by quality. Taking into account huge differences among countries, primarily concerning development level, number of types of hospitality establishments varies and changes quickly. Classification is exactly sorting and grouping of establishments into one class based on mutual characteristics, whereas categorisation comprises ranking of the same class establishments within a particular group according to quality. Institutions that prescribe the norms for the country are different, depending on the type and number of establishments that are owned either by individuals of by the country. According to that, there are various systematic solutions for classification and categorisation. A consumer selects the appropriate object to meet his needs according to the information obtained (Bradić, 2008). 
Categorisation of tourist accommodation is a coded form which would synthesize the comfort level and range of services related to the specific category (Foris, 2011). The objectives taken into consideration through adopting an official classification system can be (Foris, 2014):

1) Customers' information;

(2) The possibility to distinguish tourism accommodation structures, by implementing differentiated policies;

(3) The possibility of a higher tax burden from the state to the products (luxury hotels);

(4) A possible tariff regulation;

(5) Facilitate communication, contract closing and monitoring, in the relationship between hotels and travel agencies.

The criteria for categorisation of tourist accommodation, taken into consideration by WTO, are the following (The European Consumer Centres' Network, 2009):

(1) Comfort level:

(a) Superior (luxury, 4- and 5-star);

(b) Medium (3-star);

(c) Modest (1- and 2-star).

(2) Location:

(a) Seasonal;

(b) Mountain;

(c) Climatic hydropathical areas;

(d) Urban;

(e) Rural;

(f) Outside the cities, close to circulated areas.

(3) Functionality motivation/length of stay:

(a) Transit;

(b) Special motivation (stay).

(4) System operation:

(a) Permanent;

(b) Seasonal.

(5) Exploitation method: (a) Individual services;

(b) Associations (voluntary professional chains);

(6) Ownership:

(a) Personal ownership;

(b) Private;

(c) Governmental;

(d) Joint;

(e) Public ownership;

(f) Public property of international concern;

(g) Time-sharing.

(7) Capacity:

(a) Reduced (small hotels, up to 150 beds);

(b) Medium (medium hotels, 150-400 beds);

(c) Large (large hotels, over 400 beds).

(8) Target:

(a) Business;

(b) Interest; 
(c) Holiday.

(9) Service standards and offered facilities: (a) Complete;

(b) Economic;

(c) Self-hospitality.

To understand the essence of the classification system of tourism accommodation units related to rural tourism, from the point of view of the comfort level, the most important aspect is the regulatory activity from the international practice, which knows two different approaches in the elaboration of categorisation rules (Foris, 2014):

1. The rulemaking is assured by the authorities/institutions of the state (the national categorisation system);

2. The rulemaking is assured by the unions and professional organizations.

The Government of the Republic of Serbia, i.e. Ministry of trade, tourism and telecommunications prescribes or issues Regulation on classification and categorisation of accommodation establishments. It may be said that the current Regulation recognises the importance of regulations in rural tourism.

\section{Methodology}

Research methodology comprises collection, analysis and interpretation of data about categorisation of accommodation facilities in rural tourism on national level (Serbia), using the following documents: Serbian Law on Tourism, By-laws of the Law on Tourism, that is, the part of the Regulation on the categorization of accommodation facilities related to the categorization of accommodation in rural tourism in Serbia, Croatia and Slovenia, books, doctoral thesis, master papers in the field of tourism, as well as papers from journals dealing with this issue in the last 12 years, online databases (www.eurogites.org), etc. Moreover, in the paper is aplied analytical-synthetical method and comparative method.

\section{Development of rural tourism accommodation in Serbia}

Nowadays, rural tourism is one of the ever growing tourism products due to increasing demand and possibility to develop in various directions (combining numerous other tourism products). Serbian rural tourism product is far from the unknown since there are data from 1980s about 50 villages with 800 households and 3,000 registered beds with developed tourism offer. In 2011, rural tourism in Serbia had 32,000 beds (registered or not-registered) in rural areas, out of which 10,000 beds were exclusively for rural tourism (Master Plan of Sustainable Rural Tourism Development in Serbia, 2011). Today, about 300 rural households with 8,000 beds, offers hospitality services and generate more than 150,000 overnight stays per year (Petrović et al., 2017). It is very difficult to determine the exact number of accommodation units in rural tourism. Certainly, their number grows year after year but regardless of significant increase in the number of beds, rural tourism as a tourism product in Serbia remains underdeveloped. 
Basic prerequisite for tourism development in villages of Serbia is the application of appropriate standardisation and categorisation of services, especially for appropriate accommodation conditions. The key role in rural product development belongs to the combination of activities in rural areas with rural accommodation. Serbia needs to not only develop various activities but also to improve the existing. It is necessary to define and develop types of rural accommodation as the support for rural tourism in Serbia. Also, the level of accommodation should achieve international standards and rural accommodation should be differentiated in tourism offer of Serbia.

Current offer of rural accommodation capacity should be developed as typically Serbian rural offer with traditional accommodation in ethno villages, traditional farms, salaš (traditional farms in Vojvodina), cottages, vajat (wooden small houses without windows, usually situated in the backyard) and lodges. Minimum standards also need to be determined in rural accommodation development and in concordance with international minimum standards. Rural accommodation should in the future focus on authentic and genuine features. Branding of this accommodation type should be used as a means of future differentiation (Durman-Pušara, 2012).

Accommodation strategy within the Master Plan of Sustainable Rural Tourism Development in Serbia defines new types of accommodation that Serbia might offer: tree houses, grass igloos and ship houses. Tree houses are especially interesting for tourism development which is connected to the nature and could be implemented on Stara planina (mountain), primarily for children and young adults (Master Plan of Sustainable Tourism Development in Serbia, 2011).

\section{Historical review of regulations regarding classification and categorisation in Serbia}

The first categorisation regulation in hospitality in Serbia was enacted in 1947. It was conducted with the aim of distinguishing outstanding hospitality establishments from the other. Hotels were ranked in three categories. Quick tourism development imposed the need for adjusting the accommodation offer with the trends. Thus, a new regulation was enacted in 1955 - The Regulation for hotels and pensions categorisation. The categorisation was conducted by the Association of hospitality chambers of Yugoslavia. Hotels were ranked in four categories, each represented by a letter (A, B, C or D), pensions were ranked in three categories - the first (I), the second (II) and the third (III). At the beginning of the 1962, the Regulation was amended by Extra category for the most comfortable and luxurious hotels. Other hospitality establishments that offered accommodation did not comply with the regulations from the Regulation and were classified into hostels or inns without categorisation (Kosar, 2015).

Tourism development dictated ever growing network diversification of hospitality establishments for accommodation purposes and also the changes in the classification and categorisation. The new Regulation on categorisation of hospitality accommodation establishments was adopted in 1967 and amended in 1970. The Regulation was valid for 
the whole territory of the former Yugoslavia, comprising the following types of hospitality accommodation establishments: hotels, tourist settlements, motels, pensions and camps. Hotels and tourist settlements were categorised into five categories, represented by one letter each, with the introduction of letter L for luxurious category, and the motels, pensions and camps were categorized into three categories (I, II, and III).

The need for the adjustment with international classification standards for hospitality accommodation establishments brought to the changes in statistical records in this sector. According to the Law on Classification of services and Registry of classified units (FRY Official Gazette 31/96, 12/98, 59/98 and 74/98), hospitality services were represented with a large group named "Hotels and restaurants", that comprised the whole sector of hospitality accommodation services and food. Within the accommodation sector there were two groups:

1) Hotels

2) Camps and other accommodation facilities for short stays.

Hotels comprised the accommodation services, especially intended for shorter stays in the following establishments: hotels, motels, inns and hotels suitable for conferences.

The group Camps and other accommodation facilities for shorter stays comprised: camps, youth resorts, dorms and houses, as well as a large sub-group under the name "other, not listed accommodation establishments".

Since 1994, Serbia has been applying the Regulation on classification, minimum conditions and categorisation of hospitality establishments (RS Official Gazette 66/94, 3/95). According to that Regulation, hospitality establishments are classified into two basic groups:

1) Hospitality establishments for accommodation,

2) Hospitality establishments for food and beverages services (Article 5).

Hospitality establishments for accommodation purposes according to the Regulation (Article 6) are:

$\begin{array}{ll}\text { - } & \text { Hotel, } \\ \text { - } & \text { Motel, } \\ \text { - } & \text { Pension, } \\ \text { - } & \text { Tourist apartment, } \\ \text { - } & \text { Campist settlement, } \\ \text { - } & \text { Holiday house or flat, } \\ \text { - } & \text { Room for rent, } \\ \text { - } & \text { Resort. }\end{array}$


Hospitality establishments for accommodation also include other facilities intended for holidays and recreation of special groups of customers (children resorts, youth resorts/ hostels, mountain lodge, houses, etc.). Resorts and other establishments intended for holidays and recreation of special category of customers are closed type establishments offering accommodation and food services or only accommodation only for the employees, children or youth, members of associations and organisations or founders of the resort.

Hospitality service in Serbia was regulated by the Law on tourism (RS Official Gazette 36/2009, 88/2010,99/2011 and 93/2012) as well as by additional bylaws, among which special emphasis is on the current Regulation for the hospitality business, hospitality services, classification of hospitality establishments and minimum technical conditions for design and equipment of the establishments (RS Official Gazette 48/2012). This Regulation regulates the conditions and forms of doing business in hospitality industry, rendering hospitality services, classification of hospitality establishments, minimum technical requirements for design and equipment of hospitality establishments with regard to the form and type of services offered in or outside the establishments, in movable facilities, households and in rural tourism establishment. Pursuant to this Regulation (Article 4), the establishments are divided into following groups according to the type of services:

1) Hospitality establishments for accommodation,

2) Hospitality establishments for food and beverages,

3) Hospitality establishments.

Hospitality establishments for accommodation purposes, according to this Regulation, render the following hospitality services: accommodation, preparation and serving of food, alcoholic and non-alcoholic beverages and other usual hospitality services. Hospitality establishments for food and beverages offer the following services: preparation and serving of food, alcoholic and non-alcoholic beverages, or preparation and serving of alcoholic and non-alcoholic beverages. In hospitality establishments food and beverages are only prepared to be served and consumed on other location. The Regulation (2012) defines the following types and subtypes of hospitality establishments for accommodation: 1) Hotel, 2) Apart hotel, 3) Garni hotel, 4) Motel, 5) Tourism settlement, 6) Apartment settlement, 7) Camp, 8) Pension, 9) Hostel, 10) Inn, 11) Resort, 12) House, 13) Apartment, 14) Room, 15) Rural tourism establishment, 16) Hunting villa, 17) Hunting house, 18) Hunting hut, 19) Other establishments (lodging, "han", "konak" ethno house, villa, camping site, camping rest area, camping stop, etc.). If we compare the two latest Regulations it is noticeable that Serbian market has recognized certain new accommodation establishments, such as rural tourism establishment which is considered a step forward. However, differentiation and typisation of accommodation establishments in rural tourism and regulations is still insufficient with regard to the situation in the some neighboring countries that are members of European Union. 


\section{The role of the state and public sector in rural tourism development and accommodation standardization}

Rural tourism development with the special emphasis on agro-tourism or farm tourism has been the policy focus of the most European countries which aim at advancement of global social and economic development in rural areas which have been suffering from deagrarisation and depopulisation trends. The following measures of rural tourism development policy in EU have been applied (Petrić, 2006):

- Administrative help which includes cheaper, faster and easier access to information;

- $\quad$ Better legislation;

- $\quad$ Training; educational institutions offer training programmes suitable to the needs of potential tourist service givers;

- $\quad$ Taxing and finance: taxation system that will alleviate the life of rural establishments and other enterprises related to tourism activities in rural areas;

- $\quad$ Easier access to finance: necessary to ease the access to financial help, structural funds, beneficial bank loans; special initiative should be provided in the regions where depopulation processes are more prominent;

- Infrastructure construction;

- $\quad$ Marketing.

There are organisations in charge of rural tourism development throughout Europe, e.g. "The Non-profit Association of Rural Tourism" in Belgium, as well as regional organizations in charge of agro-tourism development, e.g. "Accrual Champers" and "Gates de Wallonia", in Wallonia and Logeren in Vlaanderen in Leuven (http://www. eurogites.org/member.php?lang=EN\&id=BE). Polish Federation of Country Tourism has been founded in Poland, where rural tourism development has been supported by the network of 16 advisory agricultural centres http://www.eurogites.org/member. php?lang=EN\&id=PL). Rural tourism development in Great Britain has been entrusted to the organisation Farm Stay UK that is National Agricultural Centre (http://www. eurogites.org/member.php?lang=EN\&id=UK). The Rural Tourism Association of Mecklenburg-Vorpommern has been the specialist organisation for rural tourism in this federal state in the north east of Germany since 1991(http://www.eurogites.org/member. php?lang=EN\&id=DE).The most significant rural tourism association in Austria is "Urlaub am Bauernhof", which was founded in 1990 and supported by the Ministry of Agriculture and Economy (http://www.eurogites.org/member.php?lang=EN\&id=AT). The National Association for Rural, Ecological and Cultural Tourism in Romania, (ANTREC) was set up in 1994 and has now over 30 branches all over the country (http://www. eurogites.org/member.php?lang=EN\&id=RO). 
The Strategy for the Development of Tourism of Serbia (for the Period 2016 - 2025) is document adopted in 2016. and presents medium-term and long term economic measures panned by the state and local administration. These were identified on the basis of the existing conditions, the anticipated impact of current policy on tourism in Serbia as well as changes and trends in the world tourist market. Rural tourism is seen as important auxiliary economic sector and branch of tourism which will improve and secure the sustainable development of rural communities. The main goal of rural tourism is to generate additional income of rural population, covering a range of tourism attractions, services and secondary activities provided by the rural population and private households (Strategy for the Development of Tourism of the Republic of Serbia, 2016).

It is believed that rural tourism would contribute to accession of Serbia to the EU (Strategy for the Development of Tourism of the Republic of Serbia, 2016). In this sense the Strategy for the Development of Tourism of the Republic of Serbia (20162025 ) gives a list of priority activities and funding programs supported by the EU that Serbia should use as a candidate country (Strategy for the Development of Tourism of the Republic of Serbia, 2016):

1. Extension service to support farmers, forest owners, small and medium-sized enterprises in rural areas to improve their economic performance and inclusion in value chain and rural tourism development;

2. Support for start-up and investment in non-agricultural activities in rural areas (rural accommodation, shops, restaurants, tours, ...);

3. Developing and updating plans for the development of municipalities and villages in rural areas;

4. Studies and investments related to the maintenance, restoration and improvement of the cultural and natural heritage of villages, rural landscapes and natural areas of high value, including socio-economic related activities, as well as raising environmental awareness for concrete actions;

5. Creation of strategic business areas, cooperation between small operators in organizing the common labor market and the use of facilities and funds for the development and / or marketing of tourism services related to rural tourism and other related activities).

Aiming at rural tourism development, the Government of the Republic of Serbia, also developed the Master Plan for Sustainable Rural Tourism Development in the Republic of Serbia which was defined as economic, social and environment priority of the Government in 2011.

Sustainable development plans are efficient response to problems of people, communities and private sector as well as promotion of rural development and ecological protection. Special emphasis is on national and regional planning and interventions in four target regions comprising Eastern Serbia, the Upper Danube Basin, South Banat and Central Serbia (Master Plan for Sustainable Tourism Development, 2011). Rural economy 
diversification on socially, economically and ecologically sustainable grounds is necessary for improvement of the quality of living, decreasing poverty and fighting against social and ecological degradation (Bogdanov, 2007).

Rural tourism accommodation facilities play a key role in advancement of rural product development that combines activities in rural areas with rural accommodation. There are estimates on strong need for improvement and development of accommodation capacities in rural areas of Serbia (Penić, 2015). Rural accommodation has the potential in offering wholesome tourism experience with adjacent rural activities (Penić, 2015). The operations to be undertaken to develop rural accommodation are defined within the Master Plan (Master Plan for Sustainable Tourism Development, 2011):

- Definition and development of rural accommodation typologies necessary for rural tourism support in Serbia,

- Improvement of accommodation quality to meet international standard requirements,

- Differentiation of rural accommodation offer in Serbia,

- $\quad$ Increase of rural accommodation capacity in target areas.

Minimum standard requirements should be set for each rural accommodation typology. They need to be defined with regard to comfort level, with special emphasis on bathrooms. The example of minimum standard is to provide bathroom for each room, not to share bathroom with other guests or even with rural establishment members. It depends on the number of the guests, but also certain types of accommodation imply shared bathrooms (youth hostels). Minimum standards have to be established for each type of rural accommodation taking into account special details that make the accommodation attractive. In addition, minimum standards should be in accordance with international standards. This should be taken into account regarding the funds for future projects and priority should be given to the projects that meet minimum standard requirements.

Rural accommodation offer should be further differentiated in order to achieve authentic and unique features. Its branding should be used as means of further differentiation. Quality labels need to be designed for rural accommodation in order to additionally guarantee quality for the tourists.

A Serbian village house and a house on the farm are two crucial accommodation types that need quality labelling, which would strengthen and advance Serbian form of rural accommodation. Labels in rural tourism should be developed in the following manner:

- $\quad$ traditional rural accommodation: accommodation in a traditional wellpreserved village with facilities for tourism activities,

- $\quad$ quality labels for houses on farms: these labels need to be used for branding Serbian houses on farms, e.g. "Salaš" farms should be labelled as traditional houses on the farm with specific architectural style. 
The examples of quality labelling houses on farms that have been successfully used in developed rural tourism destinations are the labels Farm Holiday (Austria), Farm Stay (Great Britain) and Bienvenue a la Ferme (France). One of the rural accommodation types used in tourism practice is a rural hotel. Special labels for hotels in rural areas should also be defined. The following criteria should be pursued:

- located in a rural area or its vicinity: isolated or in the town with the population under 1,000 .

- typical architectural style that preserves the unique architecture of the area/region.

- $\quad$ limited number of rooms (less than 70).

- $\quad$ specific features: F\&B unit supplied with local agriculture products.

- $\quad$ rural establishment: This label should be used for creating a strong brand typical for Serbian rural tourism accommodation. It may comprise traditionally built houses with material and architecture typical for the region. The examples of such rural tourism brands are Gates de France and English Rose.

Various types of accommodation that may be related to typically Serbian architecture and style may also comprise accommodation in traditional monasteries, cultural heritage buildings or mill houses (Master Plan for Sustainable Rural Tourism Development, 2011).

To sum up, Master Plan for Sustainable Rural Tourism Development in the Republic of Serbia was created in 2011 with clear development goals for rural accommodation quality and standard improvement and with the aim of pursuing market trends and international standards. New Regulation on categorisation standards for accommodation in hospitality in the Republic of Serbia was enacted the following year. The following analysis will present the concordance of law regulation with the Master Plan aims and whether the types of rural accommodation have been clearly defined as well as their categorisation criteria conducted by the Ministry of trade, tourism and telecommunications of the Republic of Serbia. Also, comparison with the neighbouring countries will also be presented here.

\section{Analysis of the existing laws regarding accommodation facilities (rural accommodation review) and comparison to the neighbouring countries}

Both in Serbia and the neighbouring countries, the process of categorisation is conducted by the authorities. Only the accommodation facilities are obliged to undergo categorisation process. Hospitality facilities for providing food and beverage services are not categorized. That is different from the previous regulations from 1994, according to which a variety, ,restaurants" were in the group of hospitality facilities that are categorized. Categorisation domain was regulated by the Regulation on Categorisation Standards for Accommodation Facilities (RS Official Gazette No.41/2010, 103/2010 and 99/2012). 
There are certain changes in the scope of categorisation compared to the previous regulations, which came as a result of changes in classification and concordance with the regulations in hospitality business, minimum technical requirements for hospitality business, as well as differentiation and grouping of hospitality facilities. To sum up, categorisation process is mandatory for all types and sub-types of accommodation facilities in Serbia according to the regulations in force (Regulation on Categorisation Standards for Accommodation Facilities (RS Official Gazette No. 41/2010, 103/2010 and 99/2012) :

1) Hotels,

- Garni hotels,

- Apart hotels,

2) Motels,

3) Tourism settlements,

4) Camps,

5) Pensions,

6) Houses,

7) Apartments,

8) Rooms,

9) Rural tourism establishments,

10) Hunting villas (hunting tourism facilities)

11) Marinas (nautical tourism facilities)

Categorisation standards in hospitality business comprise mandatory elements labelled by "M" and optional elements established for each category to provide additional points in concordance with the Regulation. Mandatory elements refer to minimum requirements regarding organisation, equipment and services within a certain category. Points are not assigned to mandatory elements. Elective elements also refer to organisation and equipment, services, i.e. location and design of the place. Certain number of points is assigned based on each established elective element. Regulation prescribes certain minimum of points for elective elements for each category of accommodation facilities. These elements are not precisely defined, but the owners opt for certain elements from either material or non-material criteria which are in concordance with the type and market orientation of their facilities. In case the object fails to obtain minimum points based on elective elements for a certain category, then the object cannot be ranked for that category despite the fact it meets the mandatory criteria. That is the essence of elective elements that were introduced in 1994 as a novelty regarding previous regulations in categorisation process. Newly introduced regulations proved effective since they enable hoteliers to create authentic combinations of services that are assigned appropriate points and finally create original products in hospitality. According to this, 
the points assigned for elective elements have been retained in the current regulations. The points for only elective elements are assigned to facilities of the highest category. In case there is no possibility for facilities from lower categories to achieve minimum points for elective elements, the missing points may be obtained from mandatory elements for higher category facilities (Kosar, 2015). Described procedure indicates that categorisation is a continuous process which demands higher level of professionalism and responsibility of authorities as well as the efficiency of the controlling system.

Further development of rural tourism needs the application of appropriate standardisation and categorisation of services, especially adequate accommodation. Law on Tourism refers to the segment of accommodation and food in establishments as a specific form of hospitality services. The facilities from the establishment accommodation group are subjected to categorisation conducted by local authorities, i.e. municipalities where they are located. This group of facilities, i.e. accommodation facilities in rural tourism consists of: houses, apartments, rooms and rural establishment (Law on Tourism, RS Official Gazette No. 36/2009, 88/2010, 99/2011 and 93/2012). All the facilities intended for tourists must meet the sanitary-technical requirements and organised into appropriate categories regulated by the act of the municipality authorities, which was regulated by the Regulation from the year 2012 .

Certain number of stars symbolises certain category of the object. Rural tourism facilities are categorised in the following manner (Regulation on Categorisation Standards for Accommodation Facilities, RS Official Gazette. No. 41/2010, 103/2010, 99/2012):

- Houses - in four categories: the fourth marked by one star and the first marked by four stars;

- Apartments - in four categories: the fourth marked by one star and the first marked by four stars;

- Rooms - - in three categories: the third marked by one star and the first marked by three stars;

- Rural tourism establishments - in four categories: the fourth marked by one star and the first marked by four stars;

Rural tourism establishment is a new type of accommodation object, introduced in Serbian classification in 2010, as a result of country's commitment to intensify rural tourism development and use natural and ethnic potentials of rural settlements. According to Regulation on requirements and types of hospitality business, forms of hospitality services, classification of hospitality facilities and minimum technical requirements and design of hospitality facilities, rural tourism household is a hospitality object or a group of hospitality facilities situated in a rural surrounding with elements of locals features and heritage which offers accommodation, food and beverage services. In certain instances, this Regulation also provides that rural tourism establishments may offer only food and beverage services. 
Table 1. The score based on elective elements for various types of accommodation in rural tourism in Serbia

\begin{tabular}{|l|c|c|c|c|c|}
\hline \multirow{2}{*}{\multicolumn{1}{|c|}{ Type of accommodation object }} & \multicolumn{5}{c|}{ Score/category } \\
\cline { 2 - 6 } & $5^{*}$ & $4^{*}$ & $3^{*}$ & $2^{*}$ & $1^{*}$ \\
\hline House & $/$ & 50 & 40 & 30 & 20 \\
\hline Apartment & $/$ & 45 & 35 & 25 & 15 \\
\hline Room & $/$ & $/$ & 30 & 20 & 10 \\
\hline Rural tourism establishment & $/$ & 50 & 40 & 30 & 20 \\
\hline
\end{tabular}

Source: Regulation on Categorisation Standards in Hospitality Accommodation, (RS Official Gazette No. 41/2010, 103/2010, 99/2012);

Rural tourism establishment is a new type of accommodation object, introduced in Serbian classification in 2010, as a result of country's commitment to intensify rural tourism development and use natural and ethnic potentials of rural settlements. According to Regulation on requirements and types of hospitality business, forms of hospitality services, classification of hospitality facilities and minimum technical requirements and design of hospitality facilities, rural tourism household is a hospitality object or a group of hospitality facilities situated in a rural surrounding with elements of locals features and heritage which offers accommodation, food and beverage services. In certain instances, this Regulation also provides that rural tourism establishments may offer only food and beverage services.

The above discussed special minimum technical requirements that should be met by hospitality facilities in rural establishments were additionally defined by the Regulation on minimum technical and sanitary-hygienic requirements for hospitality services in rural farms and rural tourism establishments (RS Official Gazette No. 41/2010 and 48/2012). Rural tourism establishment provides the facilities for guest to prepare food. Food and beverage services may be also offered outdoor. Mandatory requirements for food preparation and service in rural tourism establishment are identical to those intended for local household establishments: houses or apartments. What needs to be done is to clearly define the elements of organisation and equipment of a rural establishment that would contribute to original and authentic of the area it represents. Each owner of a rural establishment should invest into upgrading own hospitality standard to the highest possible level, with the highlight on original and authentic offer. In neighbouring Croatia there is a special "Regulation for owners" which prescribes that traditional establishment cannot use plastic tablecloth, Chinese curtains, machine-made carpets, etc. In return, the owner would get bonus points for exclusiveness and originality of the accommodation and may raise the accommodation price (Durman-Pušara, 2012).

According to the latest Regulation (2012) accommodation units in rural tourism establishment are rooms with or without bathroom. Mandatory elements for the rooms and bathrooms are prescribed by minimum technical requirements for accommodation establishments. Nowadays, pursuing modern trends at tourism market as well as Master Plan definition, the guests look for rooms with bathrooms in each categorised object, i.e. accommodation unit regardless the category. That is the base for further 
differentiation of rooms in rural establishments. Moreover, equipment and organisation should reflect traditional style that is different from the style in towns, spas or other tourism destinations, which is not the case according to the present Regulation.

If the rural tourism establishment also breeds domestic animals, this activity has to be organised in specially designated areas, distant from the premises intended for the guests. Such specially designated areas have to be in the area that enables good ventilation and prevent odors spreading to the areas intended for guests (Regulation on Minimum Technical and Sanitation-Hygiene requirements for hospitality services in rural tourism establishments, RS Official Gazette No. 41/2010 and 48/2012). It may be concluded that current regulation for rural accommodation is neither in compliance with the aims presented in Master Plan nor with international standards. Serbian market has only recognised and recorded various types of accommodation establishments in rural tourism, such as: farms, ethno houses, salaš-farms, cabins, vajati- small yard houses, etc. without proceeding further. The challenge for Serbia in the following years is to adjust the regulations with the Master Plan aims as well as with international standards and to classify rural accommodation and criteria for their standardisation.

The comparison with the neighbouring countries: Categorisation in Romania is based on classification conducted by the authorities. Categorisation criteria are built upon the classification criteria established by World Tourist Organisation (UNWTO). Further elaboration refers to the size of rooms, safety and security standards and certificates that confirm the staff competence. Regulations in Romania recognised the following rural accommodation types: hostels, tourist complexes, apartments and rooms for rent, bungalow, cottage, camping, tourist village, a tourist stopover, apartments and camping (Foris, 2014). In Slovenia, Regulation on categorisation of hospitality establishments (Pravilnik o kategorizaciji nastavnitvenih obratov, Uradni list RS, št. 62/2008 in 72/2009) categorised the following types: hotels, motels, pensions, inns, camps, apartments - flats and houses for holiday, rooms, farms for accommodation and marinas. Slovenian law regulation differentiated farms as a special form of accommodation in rural tourism, which is not the case in Serbia. In Croatia, the facilities that according to Regulation on differentiation, categorisation and special standards of hospitality services in the group "Hotels" (National Newspaper No. 88/2007, 58/08, 62/09, 63/13, $33 / 14$ and 92/14), fall within the mandatory categorisation group and are divided into the already existing facilities and new. Categorisation elements are specially prescribed for the existing, especially for the new facilities (Kosar, 2015). With regard to rural tourism, Croatia has advanced a lot in recognition of new types of accommodation and included them into the Regulation. Thus, Croatian regulation recognised: rooms in rural establishments, apartments, rural houses for holidays, camps in rural establishments, wine shop/wine tasting and excursion site (Regulation on changes and amendments on the regulations in hospitality services in rural establishments, (National Newspaper No. $138 / 06,152 / 08,43 / 09$ and 88/10). In this sense, neighbouring countries may serve as the example for Serbia what direction to take and how to perform developmental and administrative activities. 


\section{Conclusion}

Quintessential changes that have been accompanying the economic conditions in Serbia for a certain period (ownership transformation, market economy) impose serious demands onto the hospitality business that functions in technical-technological and organizational-staffing frameworks of various types and categories of accommodation facilities. The regulations on categorisation are a form of superstructure over minimum hospitality business standards, i.e. tourism. Categorisation and specialization are parallel processes that will be performed in the future in concordance with the prevailing market trends, i.e. modern technical-technological and organisational-staffing standards of quality. Consistent application of the standards is directed towards establishing quality and maintaining it, which would be the basic precondition for active participation of Serbia in international tourism trends. Dynamic approach to those processes means constant reconsideration and innovation, as the basic prerequisites for compliance with international standards in the EU countries. In this regard, it is estimated that rural tourism recognizes rural establishment as a new form of accommodation in rural tourism. However, this Regulation treats equally the rooms in spa resorts and rooms in rural establishments. Traditional establishment should be equipped in national and traditional style with all the details that make the offer original and authentic. Diversification of accommodation in rural tourism imposes the imperative of the recognition of new accommodation types and their inclusion into legal obligatory categorisation that will guarantee the proper quality to the guests. In the following years, Serbia need to adjust the regulations with the Master Plan aims as well as with international standards and to classify rural accommodation and criteria for their standardisation. Compared with the legislation in the countries of the region (Croatia, Slovenia, Romania), it is necessary to perform the specialization of accommodation facilities in rural tourism, to include them in the regulations, of course including all the traditional specifics that Serbia has.

\section{Conflict of interests}

The authors declare no conflict of interest.

\section{References}

1. Bradić, M. (2008). Classification and categorisation of hospitality offer in Serbia. Master Paper manuscript, Faculty of Science, Department of Geography, Tourism and Hotel Management, Novi Sad. [in Serbian: Bradić, M. (2008). Klasifikacija i kategorizacija hotelijerske ponude u Srbiji. magistarski rad (u rukopisu), PMF, Departman za geografiju, turizam i hotelijerstvo, Novi Sad.]

2. Bogdanov, N. (2007). Small Rural Households in Serbia and rural non-farm economy. UNDP - MAFWM, Belgrade.

3. Durman-Pušara, S. (2012). Possibilities for improvement of accommodation capacities in rural tourism in Serbia. Master Paper manuscript, Singidunum University, Faculty of Tourism and Hotel management, Belgrade. [in Serbian: 
Durman-Pušara, S. (2012). Mogućnosti za razvoj smeštajnih kapaciteta u ruralnom turizmu Srbije. master rad (u rukopisu),Univerizet Singidunum, Fakultet za turistički i hotelijerski menadžment, Beograd.]

4. Foris, D. ( 2011). Reglementation of tourism activities. Lux Libris Publishing House, Brasov, Romania.

5. Foris, D. (2014). Study regarding the classification of tourism accommodation units for rural tourism within the EU member states. Facultatea de management agricol, Lucrări ştiințifice, 16(4), 38-43.

6. Foris, D. (2014). Comparative Analysis of Hotel Classification and Quality Mark in Hospitality. Journal of Tourism and Hospitality Management, 2(1), 26-39.

7. Gajić,T., Vujko, A., Penić, M., Petrović, M.D., \& Mrkša, M. (2017). Significant involvement of agricultural holdings in rural tourism development in Serbia. Economics of Agriculture, 64( 3), 901-919.

8. Kosar, Lj. (2015). Hospitality I. The College of Hotel Management, Belgrade. [in Serbian: Kosar, Lj. (2015). Hotelijestvo I. Visoka hotelijerska škola strukovnih studija, Beograd.]

9. Master Plan for Sustainable Rural Tourism Development in Serbia, 2011. [in Serbian: Master plan održivog razvoja ruralnog turizma u Srbiji, Beograd, 2011.]

10. Penić, M. (2015). Quality of accommodation capacities as an indicator of rural tourism development in Serbia. Doctoral thesis manuscript, Faculty of Science, Department of Geography, Tourism and Hotel Management, Novi Sad. [in Serbian: Penić, M. (2015). Kvalitet smeštajnih kapacita kao indikator razvijenosti ruralnog turizma u Srbiji. Doktorska teza u rukopisu, PMF, Departman za geografiju, turizam i hotelijerstvo, Novi Sad.]

11. Petrić, L. (2006). Challenges of rural tourism development: European experiences and implications for Croatia. Acta turistica, 18(2), 138-170.

12. Petrović, M. D., Blešić, I., Vujko, A., \& Gajić, T. (2017). The role of agritourism's impact on the local community in a transitional society: A report from Serbia. Transylvanian Review of Administrative Sciences, 50(1), 146-163. doi:10.24193/tras.2017.0009

13. Regulation on classification, minimum conditions and categorisation of hospitality establishments, RS Official Gazette No 66/94, 3/95. [in Serbian: Pravilnik o razvrstavanju, minimalnim uslovima i kategorizaciji ugostiteljskih objekata, Službeni glasnik RS 66/94, 3/95.]

14. Regulation on Minimum Technical and Sanitation-Hygiene requirements for hospitality services in rural tourism establishments, RS Official Gazette No 41/2010 and 48/2012. [in Serbian: Pravilnik o minimalnim tehničkim i sanitarnohigijenskim uslovima za pružanje ugostiteljskih usluga u domaćoj radinosti i u seoskom turističkom domaćinstvu, Službeni glasnik RS br.41/2010 i 48/2012.]

15. Regulation on requirements and types of hospitality business, forms of hospitality services, classification of hospitality facilities and minimum 
technical requirements and design of hospitality facilities, RS Official Gazette No 48/2012. [in Serbian: Pravilnik o načinu obavljanja ugostiteljske delatnosti, načinu pružanja ugostiteljskih usluga, razvrstavanju ugostiteljskih objekata i minimalno-tehničkim uslovima za uređenje i opremanje ugostiteljskih objekata, Službeni glasnik RS br.48/2012.]

16. Regulation on Categorisation Standards for Accommodation Facilities, RS Official Gazette No 41/2010, 103/2010, 99/2012. [in Serbian: Pravilnik o standardima za kategorizaciju ugostiteljskih objekata za smeštaj, Službeni glasnik RS br. 41/2010, 103/2010, 99/2012.]

17. Regulation on changes and amendments on the regulations in hospitality services in rural establishments, National Newspaper No. 138/06, 152/08, 43/09 and 88/10. [in Croatian: Pravilnik o izmjenama i dopunama pravilnika o pružanju ugostiteljskih usluga u seljačkom domaćinstvu, Narodne novine", broj 138/06., 152/08., 43/09. i 88/10.]

18. Pravilnik o kategorizaciji nastavnistvenih obratov, Uradni list RS, št. 62/2008 in 72/2009.

19. Strategy for the Development of Tourism of the Republic of Serbia, 2016. [in Serbian: Strategija razvoja turizma Republike Srbije, 2016.]

20. UNWTO, Sustainable tourism for rural development, Project concept, 2010. [in Serbian: UNWTO, Одрживи туризам за рурални развој, концепт пројекта, 2010.]

21. Guidebook for rural hosts, Business development centre Kragujevac, Kragujevac, 2014. [in Serbian: Vodič za seoske domaćine, Razvojni biznis centar Kragujevac, Kragujevac, 2014.]

22. The European Consumer Centres' Network, Classification of hotels establishments within the EU, 2009.

23. Vukosav, S. (2010). Adjustments of hotel product in Vojvodina to contemporary trends in tourism. Doctoral thesis manuscript, Faculty of Science, Department of Geography, Tourism and Hotel Management, Novi Sad. [in Serbian:Vukosav, S. (2010). Prilagođavanje hotelskog proizvoda Vojvodine savremenim tendencijama u turizmu. doktorska teza (u rukopisu), PMF, Departman za geografiju, turizam i hotelijerstvo, Novi Sad.]

24. Law on Tourism, RS Official Gazette No. 36/2009, 88/2010, 99/2011 and 93/2012. [in Serbian: Zakon o turizmu, Službeni glasnik RS br. 36/2009, 88/2010, 99/2011 i 93/2012.]

25. http://www.eurogites.org/member.php?lang=EN\&id=BE

26. http://www.eurogites.org/member.php?lang=EN\&id=PL

27. http://www.eurogites.org/member.php?lang=EN\&id=AT

28. http://www.eurogites.org/member.php?lang=EN\&id=UK

29. http://www.eurogites.org/member.php?lang=EN\&id=DE

30. http://www.eurogites.org/member.php?lang=EN\&id=RO 